\title{
A GRASSLANDS PARK YES OR NO?
}

by MAUREEN REVER*

On March 27, 1975, Saskatchewan's Minister of Tourism and Renewable esources announced the signing of a memorandum of agreement" between he federal and provincial governhents to determine within the next 2 ears the suitability of establishing a ational grasslands park in the $\mathrm{Val}$ Marie area of southern Saskatchewan. rior to a decision being taken, public earings were promised.

In the light of the record of both rovincial and federal governments in egard to public hearings on environhental issues, some citizens' groups nd individuals with a long standing terest in seeing a grasslands park in askatchewan, are now concerned bout how the decision - yes or no ill be reached. Will the large number f letters and expressions of support or a national grasslands park already the Premier's office - letters not nly from Saskatchewan citizens but lso from other parts of North merica - be considered? Or are we tarting from scratch?

The record is not good.

The Saskatchewan government rade its debut with the public earings on a proposed plan for Meadow Lake Provincial Park. lthough many excellent briefs and omments were presented by

For the Resources Study Group, Box 276, Sub ost Office No. 6, Saskatoon, Sask. A study of the jrasslands Park is available from the author. rom Probe, June 1975 professional groups, highly skilled and knowledgeable members of the public and individual citizens with property and experience of the park area, today, almost $2-1 / 2$ years later, there has been no indication as to the conclusions reached. Furthermore, at the time of the hearings it became evident that part of the proposed plan, on which the public was being asked to comment, was already in operation. Who is fooling whom?

Then came the public hearings on the Poplar River thermo-electric plant. A quick answer - yes - a foregone conclusion. It was clear to the environmentally concerned that these public hearings were nothing but "window dressing". That the hearings were held only at Coronach made it extremely difficult for persons outside the area to attend. Briefs sent by mail may or may not have been given attention - who knows? The information given to the public less than a month before the hearings was, for the engineering aspects of the project, highly technical, and for environmental issues, totally inadequate. The panel of adjudicators had no one competent to judge the environmental impact of the project.

While the federal government has done better in making information available in advance of public hearings, thus making the preparation of briefs more meaningful, still the public has reason to question whether these hearings, too, are just "window dressing". For example, it appears that Village Lake Louise will be built in 
spite of overwhelming public disapproval of the project. Although somewhat modified from the first proposal, the federal park's design has flaws equal to, or even more horrendous than, the original Esso-proposed development.

And so we take a dim view of the announced "memorandum of agreement" to determine the suitability of establishing a national grasslands park. How can we be sure the information provided to the public prior to the hearings is unbiased? Will the pros and cons of the project be clearly stated? We should know the views of the ranchers in the area and the reasons for them; we should know whether or not there are valuable resource deposits in the area; we should be aware of the unique and fragile ecology of the area. So far, little of this information has been made available to the public. So far the public has had to make educated guesses as to what the situation reall is.

In my opinion, before the citizens Canada can make a wise decision o having a national grasslands park park that would be unique in Nort America - it would be necessary fo the governments concerned to make sincere effort to release extensive, fac tual information to the public well advance of the hearings. All intereste groups should have opportunity contribute to this. The hearings, the should be held well after the summe months and in places accessible people from other areas of th province to ensure a maximu representation and high quality cor tributions.

To gain the confidence of the publi it is necessary that those appointed evaluate the hearings are capable judging the evidence and opinions different interest groups and it

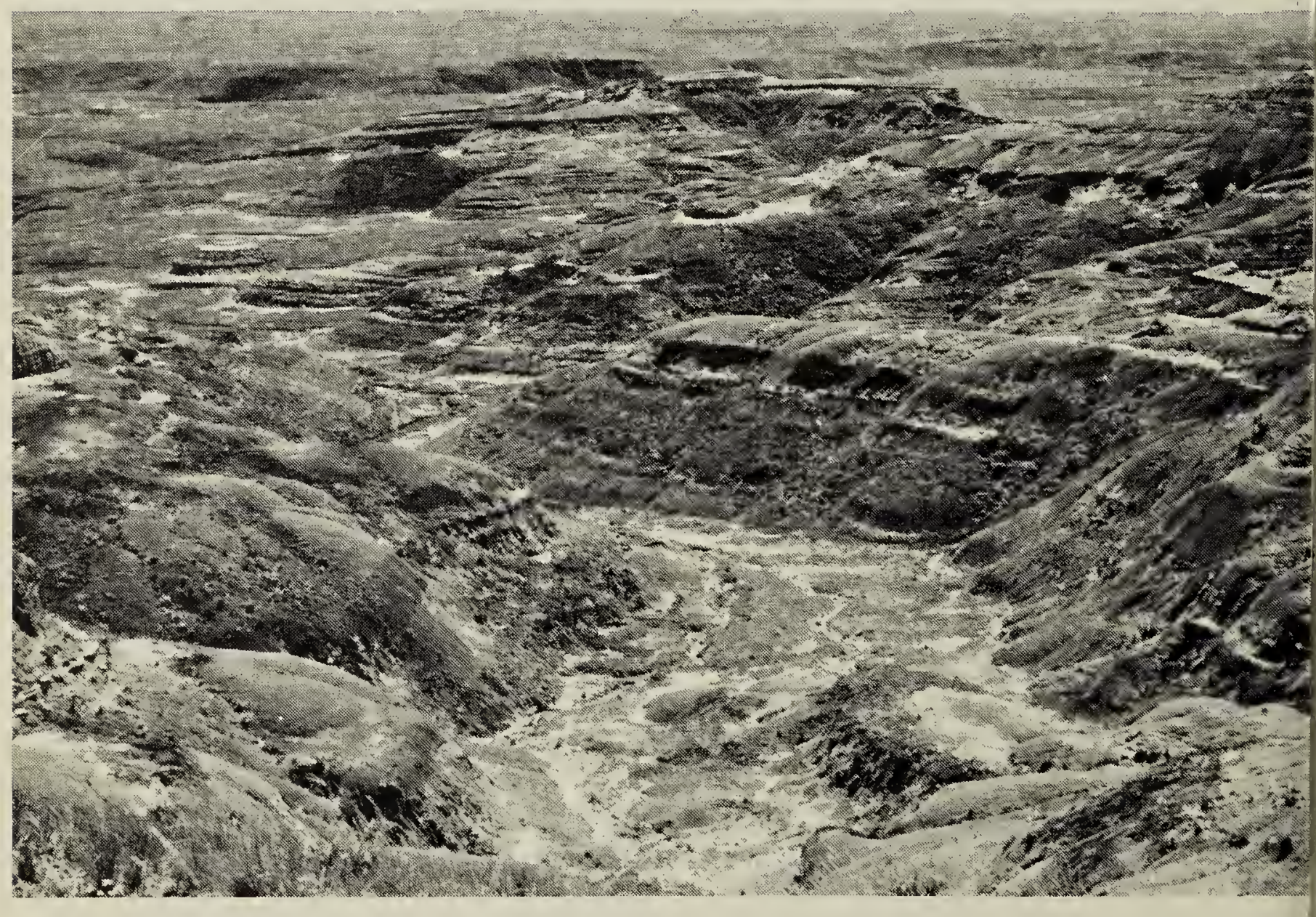


lividuals. Why, for instance, was there to representative of Saskatchewan's Environmental Advisory Council at he Poplar River hearings? The Counil was not even consulted as to whether those appointed to the panel vere qualified to make environmental udgements. Is this, the public's "Adisory Council", more official "winlow dressing"?

I do not know how much longer itizens' groups and individuals are ooing to spend the time and effort equired to prepare detailed, reasoned recommendations for any level of government unless there is a clear indication that their opinions will be given an honest evaluation. I do know that the national grasslands park is worthy of every effort by those of us who value this unique ecological treasure and strongly feel that the issue must be given serious consideration by the public. 


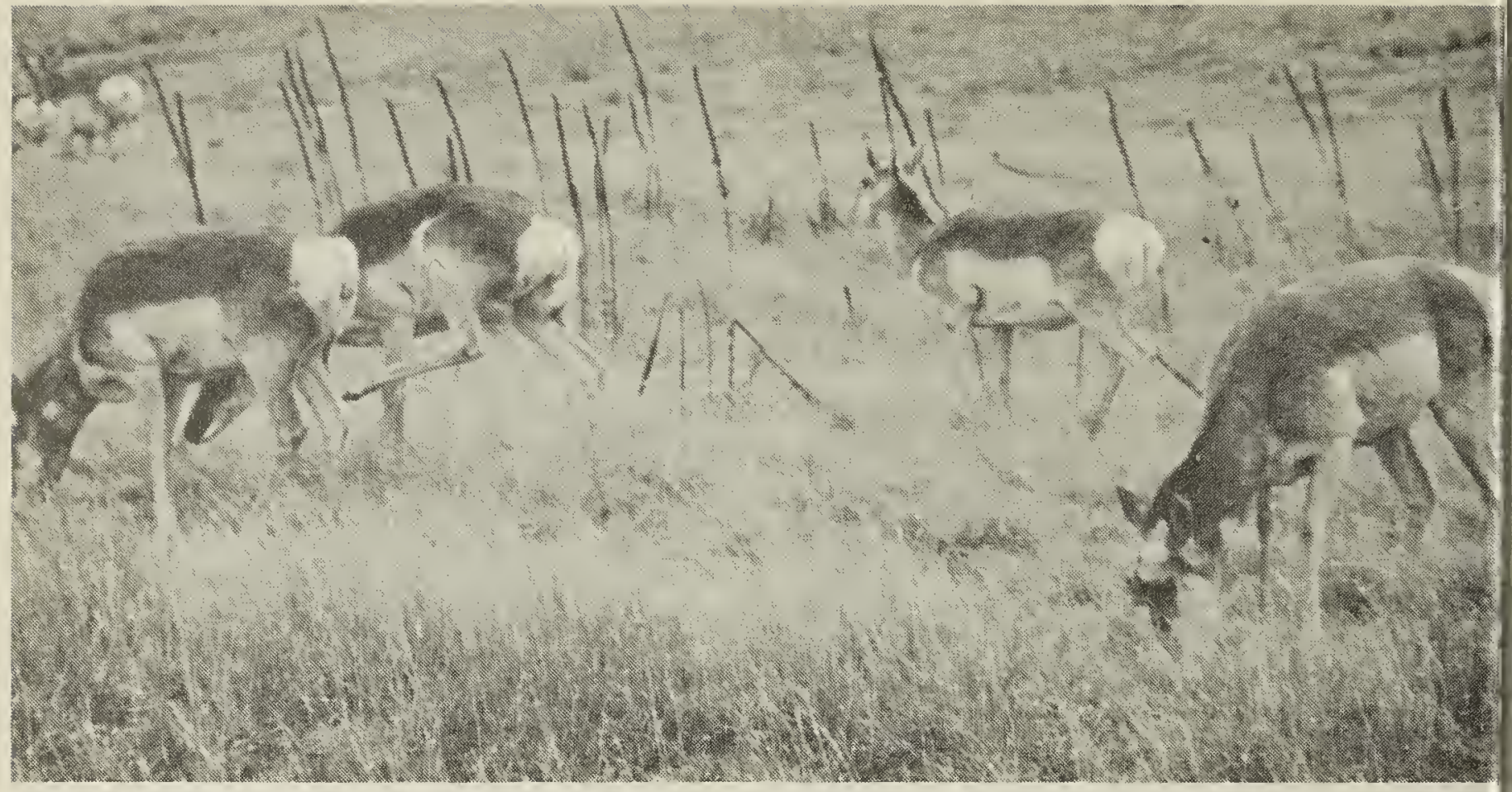

Pronghorns

Lorne Sco

\section{PARKS CANADA COMMENTS}

The following is the text of a letter dated July 10,1975 , from G. M. Davison of Parks Canada, 114 Garry St., Winnipeg, to Maureen Rever:

I read your paper on "A Grasslands Park - Yes or No" with a great deal of interest. The concerns expressed by you are relevant and are concerns of a large number of Canadians. We are also concerned with these matters and we hope that the following approach will give many people the opportunity of making their views known to us and to the Saskatchewan Government.

Parks Canada and the Saskatchewan Government are now in the process of drafting an information booklet for the Grasslands hearings, which will be sent out to interested groups and to people in the immediate area of the proposed Park. This booklet will be distributed around mid-August, thus giving the general public a chance to evaluate the contents prior to any public meetings.

On or about September 15th, the Saskatchewan Government and Parks Canada will commence holding a series of information-type meetings at various locations in the Province of Saskatchewan. These meetings are to be held with the intent to clarify ar misunderstandings that may develo as people evaluate the contents of th booklet.

The information-type meetings wi be followed by public hearings whic will commence in late fall. Again the meetings will be held in variou locations in the Province of Saska chewan, thus giving all intereste groups and individuals an opportuni to make their views known.

Your comments on biased info mation were well taken and to avo this pitfall we will be trying to prese all information as straightforward possible. In addition to this, an $\mathrm{i}$ dependent chairman will be appointe for the public hearings, theret reducing the chance of biased opinio from influencing any final decisions

The commission of enquiry will submitting their report to the $t v$ ministers sometime in December early January which will outline $t$ degree of support for the propos Park. Afterwards the Saskatchew Government will be in a position make a decision on the proposal. Yours sincerely, G. M. Davison, $f$ Director. 